\title{
Contemporary Varieties of Ethical Leadership in Organizations
}

\author{
Montgomery Van Wart ${ }^{1}$ \\ ${ }^{1}$ Department of Public Administration, California State University San Bernardino, San Bernardino, USA. \\ Correspondence: Montgomery Van Wart, Professor, Department of Public Administration, California State University \\ San Bernardino, San Bernardino, CA, USA. E-mail: mvanwart@csusb.edu \\ Received: July 30, 2014 \\ doi:10.5430/ijba.v5n5p27 \\ Accepted: August 15, 2014 \\ Online Published: August 31, 2014 \\ URL: http://dx.doi.org/10.5430/ijba.v5n5p27
}

\begin{abstract}
Classical ethics perspectives are generally sorted into the virtue, deontological, or teleological approaches, also known as the character, means (duty), and ends (greatest good) schools of ethical thought. In recent decades, the catalog of literature extolling the various types of ethical leadership has proliferated. Analysis of the six major contemporary ethical leadership perspectives that follow reveals that they can be grouped into "scientific" articulations of three dominant classical distinctions. That is, the personal integrity and authentic/positive leadership models can be seen as classic virtue approaches, looking to the individual as the primary locus of ethical action. Moral management and professionally-grounded leadership can be seen as classic deontological approaches, focusing on society's rules and roles, as spelled out through compliance or professional education. Finally, variants of the socially responsible leader and transforming leadership models can be seen as classic teleological approaches, emphasizing broad shareholder inclusiveness with "greatest-good" assumptions. Critique of each of the various varieties of ethical leadership is also reviewed.
\end{abstract}

Keywords: ethical leadership, ethics, leadership, virtuous leadership, moral management, servant leadership, transforming leadership

The connection between ethics and leadership is certainly obvious, but it is more sophisticated and complex than one might suppose after careful review of the literature. Several assertions have wide acceptance among scholars.

Perhaps the most significant among them is that not all organizational leaders "in the real world" are ethical (Padilla, Hogan, and Kaiser 2007; Schilling 2009; Einarsen, Aasland, and Skogstad 2007; Treviño and Brown 2005, Brown and Mitchell 2010). Some of the worst leaders are portraits of selfishness (Kets de Vries 1985; Rosenthal and Pittinsky 2006), self-indulgence (Powers 1987; Judge, Piccolo, and Kosalka 2009), megalomania (Caro 1974), disturbed psyches (Goldman 2006) and occasionally evil (Adams and Balfour 1998; Reed 2012) no matter whether one turns to either the private or public sector. Even some of the most successful and professional organizational leaders have lapses if they are in positions of power long enough (Sandowsky 1995; Lichtenstein, Smith, and Torbert 1995), though it might be argued that built-in controls, incentives for risk-aversion and transparency requirements in the public sector and publicly traded companies substantially reduce the tendency for egregious ethical behavior at the careerist level in advanced democracies (Goodsell 2003, Litzky, Eddleston, and Kidder 2006; Bazerman and Tenbrunsel 2011). Given the importance of trust and confidence to both private and public organizations (Kirth and Ferrin 2002; Johnson 2005; Stouten, van Dijke, and De Cremer 2012; Zhu et al. 2012) and the shattering effect of ethical lapses and scandals (e.g., Arthur Anderson's near total collapse in 2002 after the Enron scandal embroiled it in unsavory practices), it is hard to underestimate the importance of ethics and leadership for long-term organizational health and survival (Kaiser, Hogan, and Craig 2008; Trottier, Van Wart, Wang 2008).

It is interesting to note that not all theories of leadership have an ethical thrust or overt ethical element to them (Rost 1990). Machiavelli's advice to princes recommends that although they should have a public persona of Aristotelian virtue, they must also be pragmatic in their use of brute force, patronage, and subterfuge (Machiavelli 1998). Nineteenth century heroic leadership models assumed good intent but also came with an assumption of great license to figures such as Napoleon who could be condemned for devastating Europe through wars, but commended for creating the modern administrative state (Engund 2004). The reinvented and more sophisticated theoretical form of heroic leadership in the twentieth century, transformational leadership, has grappled with how to balance the need for strong and charismatic leaders to aid the change process, especially in times of great crises, alongside the need for personal restraint and sensitivity to social values (Burns 1978; Bass and Steidlmeier 1999; Conger 1989). Descriptive 
transformational models must deal with the variation between the appearance and reality of ethical behavior, short-term versus long-term goals, the selfishness of an in-group versus the needs of society, etc. Transactional theories emerging in the 1960s and 1970s added humane concern for people into advice for production based on pragmatism in models such as the Managerial Grid (Blake and Mouton 1964), Situational Leadership (Hersey and Blanchard 1969), LMX (Graen and Cashman 1975), the Normative Decision Theory (Vroom and Yetton 1973), and others. The ethical implications were invariably avoided as outside the scientific realm. The lack of an overtly ethical thrust here is not necessarily a critique. Theories are analytic tools to understand phenomena. If ethical issues are not one's primary concern or ethical behaviors can be safely assumed, then a lack of emphasis on the leader's ethics may indeed make sense.

Fortunately, there are many theories of leadership that do emphasize ethical behavior, and indeed, in a variety of disciplines (Eisenbeiss 2012). What is thought-provoking is that not all theories agree on the critical focus of ethical leadership (Dion 2012). Indeed, as more analytic work has been done on ethical leadership, the variation among schools of thought appears to have grown (Brown and Treviño 2006). The thesis of this article contends that while superficially this may seem to be confusing, a deeper analysis indicates that these different schools of thought are generally exploring historical ethical themes in a more articulated and systematic way.

\section{Three Historical Perspectives on Values-Based Leadership}

Ethics-based approaches tend to have three major concerns or pillars (Beck-Dudly 1996; Ciulla 2004; Ciulla, Price, Murphy 2005). The first concern is the intent of individuals, no matter whether leaders or members of the organization. The character of individuals affects their ability to be a moral force in the organization, and potentially, improve effectiveness. Yet this raises the question, is the intent of individuals based primarily on being honorable, or does good intent require other traits in order to demonstrate strong ethical character? Aristotle (1953) is a primary example of virtue or character ethics (eudaimonism).

A second concern is selecting the proper means for doing good. In classical philosophy, this is the deontological approach. Being moral means knowing and following appropriate social customs that stem from laws, rules, and mores. Yet as situations become more complex, what is the leader's role in dealing with the competing and conflicting values that emerge? Kant (1787/1996) is perhaps one of the best known for his ethics of duty, via his grand categorical imperatives, in an orderly society.

A third concern is in selecting the proper ends. In classical philosophy, this is the teleological approach. For whom or what is one acting? Ethical leaders act for their constituents, followers, society, and the environment. When organizational or social change seems to be required, and yet social consensus is fragmented, action itself is difficult and determining what is ethical is especially challenging. An example of a school of philosophy emphasizing ends via articulation of greatest-good models of ethical reasoning is the utilitarian perspective such as the philosophy of John Stuart Mill (1863) who espoused a kind of ethical cost-benefit analysis across appropriate stakeholder individuals and groups.

Most would agree that all three concerns - good intent, proper means, and appropriate ends, or, stated differently, character, duty and greatest good - must be functioning for good leadership (as a process) to be robust (Ciulla 1995). Systems with ethical leadership tend to provide a higher quality of life for all individuals involved, higher organizational performance on average, greater sense of trust and pride for those affected, and greater sustainability over time (e.g., Stouten, van Dijke, and De Cremer 2012). Many ancient religious and ethical philosophies contain elements of all three of these pillars of conduct (Ip 2011; Sheth 2005), even though they may be particularly well known for a specific aspect. Similarly today, many theorists provide frameworks that accommodate a blend of intent, means and ends, yet many focus on specific ethical pillars. The analysis provided here demonstrates that different schools of thought, though seemingly somewhat incongruous, are largely complementary when the greater tripartite picture is viewed. Rather than being in conflict, each perspective simply provides a deeper analysis of ethics and leadership. Six loose "schools" of thought are highlighted, two for each ethics pillar, with an eye to emphasizing their distinctiveness without damaging their overall approach. Concerns for proper intent are examined by those emphasizing virtuous leadership, and authentic and positive leadership. Concerns for proper means are examined by those emphasizing moral management leadership and professionally grounded leadership. Concerns for proper ends are examined by those emphasizing social responsibility leadership and transforming leadership. The analysis will discuss some of the major variants within each of the six schools of thought where structurally useful, but for space and clarity, will not delve into the many variations among specific commentators. An overview of the six perspectives is arrayed in Table 1. Finally, while descriptions of the six schools will highlight their contributions, this is followed by a short discussion of the types of issues and challenges that each school of thought currently raises. A general critique of 
specific ethical theories concludes the article.

Table 1. Overview of values-based leadership theories emphasizing distinct foci

\begin{tabular}{|c|c|c|c|c|}
\hline $\begin{array}{l}\text { Type of Ethical } \\
\text { Leadership }\end{array}$ & Aligned concepts & $\begin{array}{c}\text { Major Ethical } \\
\text { Concerns }\end{array}$ & Major Emphases & $\begin{array}{c}\text { Modern } \\
\text { Proponents }\end{array}$ \\
\hline \multicolumn{5}{|l|}{$\begin{array}{l}\text { PROPER } \\
\text { INTENT }\end{array}$} \\
\hline $\begin{array}{l}\text { Virtuous } \\
\text { Leadership }\end{array}$ & $\begin{array}{l}\text { Personal integrity } \\
\text { model; the "man } \\
\text { of honor" } \\
\text { approach }\end{array}$ & $\begin{array}{l}\text { - Concern for } \\
\text { integrity } \\
\text { - Concern for doing a } \\
\text { good job } \\
\text { - Wisdom } \\
\end{array}$ & $\begin{array}{l}\text { - Honesty } \\
\text { - Trustworthiness } \\
\text { - Fairness } \\
\text { - Conscientiousness } \\
\text { - Prudence }\end{array}$ & $\begin{array}{l}\text { MacIntyre, } \\
\text { Solomon; generally } \\
\text { assumed in some } \\
\text { fashion by nearly } \\
\text { all ethicists }\end{array}$ \\
\hline $\begin{array}{l}\text { Authentic and } \\
\text { Positive } \\
\text { Leadership }\end{array}$ & $\begin{array}{l}\text { Primal leadership, } \\
\text { resonant } \\
\text { leadership }\end{array}$ & $\begin{array}{l}\text { - Concern for one's } \\
\text { own principles and } \\
\text { values } \\
\text { - Concern for } \\
\text { self-regulation } \\
\text { ("positive" } \\
\text { leadership) leading } \\
\text { to confidence, } \\
\text { optimism } \\
\text { resilience, etc. }\end{array}$ & $\begin{array}{l}\text { - Self awareness } \\
\text { - Self improvement } \\
\text { - Open to feedback; } \\
\text { nondefensive } \\
\text { - Transparency } \\
\text { - "Positive" influences on self } \\
\text { and followers }\end{array}$ & $\begin{array}{l}\text { Avolio and } \\
\text { Gardner, Argyris, } \\
\text { Covey, Luthans; } \\
\text { Goleman and } \\
\text { Boyatzis }\end{array}$ \\
\hline \multicolumn{5}{|l|}{$\begin{array}{l}\text { PROPER } \\
\text { MEANS }\end{array}$} \\
\hline $\begin{array}{l}\text { Moral } \\
\text { Management } \\
\text { Leadership }\end{array}$ & $\begin{array}{l}\text { Ethics training, } \\
\text { the low road } \\
\text { approach }\end{array}$ & $\begin{array}{l}\text { - Concern for legal } \\
\text { and organizational } \\
\text { rules }\end{array}$ & $\begin{array}{l}\text { - Strict ethical compliance } \\
\text { with legal mandates or } \\
\text { organizational rules, e.g., } \\
\text { codes of conduct }\end{array}$ & $\begin{array}{l}\text { Legislative bodies, } \\
\text { ethics } \\
\text { "watchdogs," } \\
\text { Brown and Treviño }\end{array}$ \\
\hline $\begin{array}{l}\text { Professionally } \\
\text { Grounded } \\
\text { Leadership }\end{array}$ & $\begin{array}{l}\text { Ethics education, } \\
\text { the high road } \\
\text { approach; } \\
\text { professional } \\
\text { integrity model }\end{array}$ & $\begin{array}{l}\text { - Concern for legal } \\
\text { and organizational } \\
\text { principles }\end{array}$ & $\begin{array}{l}\text { - Knowledge of original } \\
\text { authority } \\
\text { - Ability to interpret } \\
\text { competing sources of } \\
\text { authority } \\
\text { - Codes of ethics (aspirations } \\
\text { rather than rules) }\end{array}$ & $\begin{array}{l}\text { Professional } \\
\text { organizations; } \\
\text { Rohr, Rosenbloom, } \\
\text { Sergiovanni }\end{array}$ \\
\hline \multicolumn{5}{|l|}{$\begin{array}{l}\text { PROPER } \\
\text { ENDS }\end{array}$} \\
\hline $\begin{array}{l}\text { Social } \\
\text { Responsibility } \\
\text { Leadership: } \\
\quad \text { Servant, } \\
\text { Spiritual, CSR }\end{array}$ & $\begin{array}{l}\text { affective } \\
\text { leadership, } \\
\text { exemplar } \\
\text { leadership }\end{array}$ & $\begin{array}{l}\text { - Concern for others } \\
\text { (followers or clients) } \\
\text { - Righteousness } \\
\text { - Concern for the } \\
\text { community } \\
\text { - Concern for } \\
\text { environment }\end{array}$ & $\begin{array}{l}\text { - Care and compassion } \\
\text { - Hope, faith, and spiritual } \\
\text { well-being } \\
\text { - Work as a "calling"; } \\
\text { emotional labor; courage and } \\
\text { sacrifice } \\
\text { - Sustainability } \\
\end{array}$ & $\begin{array}{l}\text { Greenleaf, } \\
\text { Newman and Guy, } \\
\text { Fry, Cooper and } \\
\text { Hart }\end{array}$ \\
\hline $\begin{array}{l}\text { Transforming } \\
\text { Leadership }\end{array}$ & $\begin{array}{l}\text { Adaptive } \\
\text { leadership, } \\
\text { transformational } \\
\text { leadership }\end{array}$ & $\begin{array}{l}\text { - Concern for making } \\
\text { wholesome change } \\
\text { - Concern for } \\
\text { wholesome change } \\
\text { process }\end{array}$ & $\begin{array}{l}\text { - Shared organizational or } \\
\text { community vision } \\
\text { - Organizational or } \\
\text { community adaptation } \\
\text { - Intellectual stimulation to } \\
\text { improve organization or } \\
\text { community }\end{array}$ & $\begin{array}{l}\text { Burns, Bass, } \\
\text { Heifetz, Bryson } \\
\text { and Crosby }\end{array}$ \\
\hline
\end{tabular}




\subsection{Virtuous Leadership (Personal Integrity Model)}

Nearly all ethical theories focus on, include, or assume basic leader integrity. Thousands of years ago Confucius stated that the strength of the nation is the integrity of its homes. More recently, military commander and President, Dwight Eisenhower, noted that the supreme quality of leadership is unquestionably integrity. The basic meaning of integrity is wholeness, and that, in turn, is based on notions of consistency with one's own words, thoughts, principles, actions, and social setting. When asked about all possible leader characteristics, the various elements of integrity are often the highest, frequently ranking more highly than competence itself (Kouzes and Posner 1993). However, lists of virtues have been generated for thousands of years, and thus vary somewhat by culture and context. Examples of major proponents include Aristotle (1953), the contemporary philosopher Alasdair MacIntyre (1981), and the business ethicist Robert Solomon (1992). Lists of virtues often include more than integrity, such as virtues relating to personal habits, compassion, sustainability, aesthetics, and theological belief. (Note 1) For the purpose of this discussion, virtues other than integrity and diligence (fulfilling one's role) are reviewed in later types of ethical leadership where they are emphasized. The five most common hallmarks of integrity are honesty, trustworthiness, fairness, prudence, and conscientiousness.

The first level of honesty is telling the truth in all oral and written expression. Honest people from this perspective do not tell lies, even refraining from "white" or courtesy lies. Further, they are truthful in both private as well as public situations. Truth telling occurs in a variety of venues, from admitting mistakes to filing taxes. A higher level of truth telling is coming forth with appropriate information when not compelled to do so; this is often called forthrightness. Secrets and "lies of omission" are not associated with honest people.

The second element of integrity relates to trustworthiness, and can involve several elements. Trustworthy people know what their principles are and are able to state them so that others know "where they stand." Of course, trustworthy people are consistent with own their principles (Manz, et al. 2008; Palanski and Yammarino 2009). In the public sector, principles are expected to include dedication to public service, commitment to the common good, dedication to the law of the land, and other civic virtues. Further, very important in being considered trustworthy in any sector is following through on a commitment, which is often called credibility. Many people make commitments cavalierly, if innocently, damaging their credibility with others. "Trust has been identified as one of the most frequently examined constructs in the organizational literature today" (Burke et al. 2007) and is sometimes used more broadly as a synonym for the concept of integrity as used here (Newell, Reeher, and Ronaye 2008).

A third major element of integrity is fairness. Fairness implies knowing and following rules and making sure that they apply to all. Because those with management and executive responsibilities have much discretion, fairness is important in both the equality of treatment, as well as in making rational and appropriate exceptions. A management nostrum is that although your enemies may report you, it is your friends who are more likely to get you into trouble. That is, turning a blind eye to the peccadillos or problems, and/or providing excessive assistance to those close to a leader can be a significant source of vulnerability and can diminish others' sense of fairness tremendously (Graen and Uhl-Bien 1995). Those who are considered very fair are not involved with "self-dealing" or using their position for personal gain rather than sharing gain more equally (Carnevale 1995, 23). Finally, because balancing various responsibilities and concerns is often a complicated matter, fair people take the time to listen well to all sides in disputes.

Wisdom, at one level, can be interpreted as deep understanding of things and people, not only understanding facts and how phenomena operate in both concrete and abstract ways, but understanding why things are as they are. Wise people blend their experience, knowledge, and reason to make optimum or prudential decisions (Kodish 2006). For Aristotle, one could not be wise without honesty, fairness, and trustworthiness, but those virtues together did not assure wisdom, a crucial acumen for leaders charged with decisions of great import.

A final virtue is conscientiousness or the concern for doing a good job. Related ideas and synonyms include diligence, industriousness, hardworking, reliability, accountability, discipline, resolution, and fortitude. It is sometimes omitted from virtue lists that focus on personal traits rather than performance (although it is included in the seven cardinal virtues, among others), but is certainly common in organizational and professional settings. At a basic level, conscientiousness is forming good habits and working earnestly, and at a higher level it includes striving for excellence.

People of good integrity are perceived as telling the truth, acting consistently, providing treatment to others that they themselves would like in the same position, acting with discernment, and aiming for excellence. Those of exceptional integrity likely exhibit remarkable candor, conscientious follow-through, and an unusual astuteness in achieving a balance in meeting the competing interests inherent in the complex situations of life (Kodish 2006). The classical expression for those with integrity, prudence and conscientiousness is "person of character." 
As useful and attractive as a focus on virtues as ethical theory, the theoretical and practical reliance on such a perspective provides a number of substantial issues to address (Mackie 1977; Louden 1984; Erwin 1995; Morse 1999). The articulation of virtues can degenerate into simplistic lists without much cohesion. So deciding whose list is used and on what grounds is a significant accomplishment at a group level. This is quite a philosophical quagmire and is often solved like the cutting through of a Gordian knot by applied ethicists. Ethics lists are notoriously weak as tools to determine priorities when values inevitably compete. To what degree does a virtues list for society as a whole have to overlap with lists for different sectors, or even different organizations? This is an enormous challenge for all applied fields, but particularly for the businessperson, where the principle of purposeful selfishness can be juxtaposed against the meaning of morality itself. There is the issue of the degree to which virtues are instinctive or cultivated. It is generally considered a mix, but determining the relative balance of the mix is also problematic. Answers to the instinctive/cultivated divide have considerable personnel selection ramifications, as well as training and education assumptions. There is also the challenge of deciding whether there is a hierarchy of virtues, e.g., cardinal virtues, or secondary virtues. Conversely, what is the role of anti-virtues, peccadilloes, or cardinal sins, and do they have a hierarchy as well? A final critique is that virtue is simply not enough to explain the complexity of ethical behavior which is why it is generally coupled with other perspectives reviewed below.

\subsection{Authentic and Positive Leadership}

If the virtuous leader emphasizes the ethical traits which promote equality and socially-oriented values, then authentic leadership emphasizes the traits that ensure self-awareness and self-improvement, and positive leadership emphasizes the traits that reflect openness, transparency and optimism. Predecessors of the authentic conceptual framework include Argyris (1957, 1993), Covey (1990), and Fairholm (1991); positive thinking harkens back to Dale Carnegie (1936) and Norman Vincent Peale (1952) and today is considered a subfield in psychology (Seligman et al. 2005). Two of the major proponents of authentic leadership are Avolio and Gardner (Avolio and Gardner 2005; Garner et al. 2005). Major proponents of positive leadership are Luthans (Luthans 2003, Luthans and Youssef 2007; Norman, Avolio, and Luthans 2010) and Wright (2003) as well as some of the scholars using emotional intelligence to explore leadership (e.g., Goleman, McKee, and Boyatzis 2002; Boyatzis and McKee 2005). Proponents of this broad school of thought tend to focus on what they perceive gives rise to successful and effective leadership; the normative and ethical aspects are wont to be secondary in their discussions (for an exception, see May et al. 2003). Nonetheless, the ethical implications of the assumptions are quite substantial (Ford and Harding 2011; Collinson 2012). Although authentic and positive leadership are analytically distinct, they are similar enough that proponents frequently publish together (e.g., Avolio and Luthans 2006). To simplify, and for the purpose of this discussion, we treat authentic and positive leadership as a blended school of thought and use the term authentic leaders for the overarching concept.

Authentic leaders are self-aware in terms of their values, cognitions, and emotions. Core values of authentic leaders include trustworthiness, credibility, respect for others, fairness, accountability and other aspects of basic personal integrity discussed above. They are adept at self-regulation in terms of their emotional intelligence, self-improvement goals, and balanced congruence between their actual and ideal selves. Authentic leaders control their ego-drives and defensiveness, which encourages openness, feedback, and a sense that genuine communication is taking place. This self-awareness and self-acceptance increases the transparency in the communication of their values, identity, emotions, goals, and motives to others. Because of this, authentic leaders develop positive psychological capital with followers whose self-awareness is also enhanced and whose authentic interaction becomes more likely. However, while the overlap with other ethical theories can be extensive to the degree that proponents of this perspective seek an all-inclusive ethical approach to leadership, it is the emphasis on self-awareness, self-regulation, and "positive" traits (e.g., optimism, self-confidence, resilience, energy) that set it apart for this discussion.

Strengths of the authentic leadership approach are numerous. The authentic leadership construct takes into account the individual's role beyond the mere passive acceptance of social norms; authentic leaders are responsible for being both self-aware and self-regulating, while translating that understanding into positive emotional behaviors (for applied examples, see Phillips and Loy 2003 and George 2003). It emphasizes the positive aspects of leadership in terms of leaders taking charge of their emotional health and enhancing the moral awareness and emotional health of others. As such, it therefore superimposes an ethical perspective on traits commonly highlighted in leadership taxonomies.

Although authentic and positive leadership have much in practice and science to commend them, their articulation has been heavily criticized as methodologically and philosophically flawed. Methodologically, critics (e.g., Cooper, Scandura, and Schriesheim 2005) have noted a number of weaknesses in developing this "very normative approach." First, the definitions of authentic leadership seem somewhat amorphous and all-inclusive, and definitions become circular. Good leaders are authentic and vice versa. There seems to be little consensus as to the exact constructs that 
make up authentic leadership, authentic leadership development, and authentic followership. Consequently, this leads to significant measurement issues and levels of analysis issues. As theorists work at setting up more elaborate research protocols, the distance between their research and practitioner accessibility seems ever greater. Further, authentic leadership has specifically been faulted as given to superficiality, naïve idealism about the human psyche, and inclined toward the egoistic (Hill, Stephens, and Pamplin 2005; Sinclair 2010; Ford and Harding 2011; Shaw 2010). Criticism focusing on the philosophical foundations of positive leadership has decried it as emphasizing an unnatural and unhealthy level of optimism, prone to organizational usurpation, and predisposed to downright hucksterism (Fineman 2006; Hackman 2009; Shipman and Mumford 2011; Collinson 2012). In the extreme, it is easy to envision the search for authenticity as self-indulgent on one hand and excessively subjective and opening up the possibility of usurping organizational and social values. Positivity is delightful in small doses but can also lead to cultish, cliquish, or superficial behaviors. Indeed, the real likelihood of the emphasis on the positive becoming a type of management-oriented group-think is well known. Finally it is important not to castigate the negative perspective which is a part of human experience, and importantly, or banish realistic planning regarding negative outcomes and external disasters.

\subsection{Moral Management Leadership}

Certainly one of the first mandates of ethical leaders and an ethical leadership process is to make sure that the rules, regulations and expected mores are:

explicitly stated,

clearly and fully taught to new organizational members,

refreshed and updated for veteran members, and

enforced consistently and fairly for all.

Organizations depend on members to know and follow their "duty" (Finer 1941; Treviño, Weaver and Reynolds 2006). Moral management is a term used to describe the leadership function of ensuring that organizational expectations are understood and enforced (Brown and Treviño 2006). The approach is also sometimes called ethics training, the low road approach, or the compliance model. This approach is not only expressed in legislative and regulatory documents, but in codes of conduct, oaths of office, and professional standards documents as well (Menzel 2007).

Moral management is highly utilized in public sector organizations in which the delegation of authority to work on the public's behest derives from statutes and is articulated through administrative law (Roberts 2009). Just as the content of what ethical public leaders are supposed to accomplish is stipulated in authorizing statutes, often the expectations of leaders to avoid self-serving or inappropriate behaviors are stipulated in so-called ethics legislation (legislation clarifying prohibited behavior such as conflict-of-interest, gift taking, nepotism, revolving door positions, etc.). While political corruption is significant in developed democracies, it certainly pales in comparison to developing countries and non-democracies with low transparency (Transparency International).

Yet virtually all private sector organizations are increasingly pursuing a more activist approach to moral management as well. Defense contract scandals and legal pressures began to increase in the U.S. in the 1990s with new guidelines by the U.S. Sentencing Commission stating that without ethics compliance programs, sentencing would increase and executive responsibility would be more extensive (McKendall, DeMarr, and Jones-Rikkers 2002). Pressures have further increased since 2001 with a wave of accounting scandals in the U.S. and the post-2008 financial crisis, as well as a number of safety and environmental conflicts around the world. Legal pressures on corporations increased through a series of laws, most notably the 2002 the U.S. Sarbanes-Oxley Act which made the requirements for ethics training and codes of conduct more robust, as well as the requirements for internal enforcement resources (Fiorelli and Tracey 2007) and new financial regulation legislation in 2010 (which only partially replaced the level of financial regulation prior to deregulation occurring with the dismantlement of the iconic U.S. law, Glass-Steagall). In the UK, the financial recession of 2008 led to the Walker Report (2009) and the UK Corporate Governance Code of 2010; corporate governance on the continent has lagged due to the challenges of fewer widely-held companies (Enriques and Volpin 2007).

The importance of moral management is most obvious in its poor implementation or absence when there are numerous private sector scandals (Dalla Costa 1998). While administrative (as opposed to political) scandals in the public sector are less common to this extent or degree or gravity, when they do occur they tend to rock public confidence far beyond their organizational jurisdiction. Recent examples include the egregious complicity of the London Metropolitan Police for their lax investigation and "coziness" during the phone-hacking scandal in Great Britain (Chandrasekhar, Wardrop and Trotman 2012) and the corruption and agency capture of the U.S. Minerals Management Agency that contributed 
to the BP Gulf oil leak in 2010 (Dlouhy 2010). More conventional examples lead to lawsuits against public agencies, loss of public confidence, and the fall of governments.

There are a number of strengths inherent in moral management. Because the U.S. and other advanced nations are nations of law, a duty and compliance approach is not culturally inconsistent, in spite of a strong streak of individualism (Wilson and Kelling 1982; Smith and Dubbink 2011). A rules approach assists agencies in creating a shared vision and method (Svara 2007). Because laws, regulations, and organizational rules are often complex or nuanced, an ethics training perspective gives due deference to the time and focus necessary for sufficient mastery of this aspect of organizational functioning. Not enforcing rules can lead to moral decay and employee disenchantment (Treviño 1992). Finally, knowing the rules and regulations gives employees confidence and enhances the public's trust (Gilman 2001; Valentine and Barnett 2003). These are enormously important considerations and are often directly or implicitly included in broader theories of ethical leadership along with the basic integrity model.

The duty or compliance approach also has many potential weaknesses. Three primary sources of problems are: an excessive focus on prohibition and excessive negativism, poor implementation, or the problem of dealing with executive corruption. When the sole focus of ethical leadership is based on compliance, it is often called the "low road" approach, signifying both a single path to complex undertaking, and the easier route because it is a "technical" solution to the problem of wrong doing (Rohr 1989). However, being ethical is not exclusively prohibiting wrong doing, and reacting to threats against integrity (Kaptein and Schwartz 2008). Being ethical is also about doing the right thing and doing things right, which are active, not passive pursuits (Thoms 2008). Further, higher stages of morality are not only founded on avoidance behavior, but on principle-centered behavior (Kohlberg 1981) which the compliance approach neglects when it is not blended with other perspectives. In terms of implementation, the building of an ethical organization can be inadequate because the perspective effort is too narrow (Di Toro 1995) or has insufficient active engagement by key stakeholders (Ladkin 2006). A code training perspective can suffer with poor materials, superficial or lackluster training, lack of pertinent examples, contradictory role models, poor discipline and so forth (Warner and Appenzeller 2011; Singh 2011). Perhaps the trickiest aspect of moral management is when the authorized source or enforcer of moral management is itself corrupted, or perceived to be corrupt. Extreme historical examples make this problem provocative: Hitler ordering subordinates to run death camps, a president ordering a cover-up of his own overreach of power, or an official selling government privileges for payoffs. A stark private sector example is the fact that Enron had a 64 page Code of Ethics which did little to prevent corporate executives Ken Lay and Jeffery Skilling from ignoring the most basic ethical mandates (Miller 2002). In such instances the wrong-doing is obvious (in retrospect) so it is really a discussion of courage in following social norms rather than improper orders (Beenan and Pinto 2009). But the issue is complex and highly challenging when social rules dictate one thing, but one's own conscience dictates another, as happens in controversial social issues such as abortion rights or in whistleblowing (O'Leary 2006). Complexity of issues is the nature of the contemporary organizational world (Pache and Insead 2010) which is reported as an increasingly significant cause of emotional exhaustion (Kammeyer-Mueller, Simon and Rich 2012).

So despite virtues of some moral management (Hood 1996; Peters 1991), there are many other challenges that it raises having to do with quantity (Howard 1994), quality (Ostrom 1996), and societal maladies that are institutionalized (Ciulla 2012; Temple 2012). Ethical systems have to ensure that a narrow moral management does not lead to rigidity by leaders in terms of excessive cautiousness, micromanagement, and inflexibility. Years of legal accretion at the societal level or making rules for obscure managerial convenience can be stifling to individual initiative so it is also important that moral management not lead to excessive job narrowing or shirking broader leadership responsibilities. A symptom of this is called "vicious compliance" when employees do whatever they are told not matter whether it is sensible or right. Good ethical systems are also sensitive to avoiding a culture in which excessive legalism and an adversarial system provide a perverse incentive not to get along. This can be seen in systems with strong moral management systems that have become proxies for management's concerns, counter-poised against tenure systems with a litigious climate, and a culture of using legalistic dispute mechanisms for minor disagreements. The challenges in building moral management systems in multicultural and multinational contexts are especially challenging. This ultimately begs the question, is a global virtue ethics really possible (Hilliard 2001)?

\subsection{Professionally-Grounded Leadership}

If the moral management approach seeks to limit discussion and variance by providing detailed authoritative guidelines by experts and lawyers, making duty as clear and technical as possible, the professionally-grounded approach does the opposite in terms of revealing complex issues and putting ethical decision making squarely into the 
orbit of responsibility of professionals (Friedrich 1940; Rohr 1989; Sergiovanni 2007). Those advocating professionally-grounded leadership emphasize broad-based education using original sources of authority and training in decision making that aid in distinguishing competing values. If moral management is rules based, professionally-grounded leadership is principles based. If moral management tends to rely on codes of conduct that are technical and stipulated to prevent wrong-doing, professionally-grounded leadership tends to rely on codes of ethics that are aspirational in terms of encouraging right-doing and exemplary behavior.

One strength of this approach is that it recognizes that many of the truly significant ethical issues are discretionary. Both senior and middle managers often have the responsibility to make reasonable exceptions to policies; training in dealing with competing values and making decisions that are consistent and defensible is much improved with professional education. Professional education also aids in uncovering the values and hidden assumptions made in everyday decisions and when really tough choices are faced. Rushing a product to market may have a number of safety, environmental, and financial risks; the reduction of personnel may have an enormous impact on customer or citizen service levels. Additionally, this approach does not treat managers and executives as automatons, but as professionals whose deliberations matter, who should always be on the lookout for problems, unfairness, and inequity, and who should always be able to detect inappropriate behavior (Sandler 2007; Stansbury 2009). As importantly, this approach tries to inspire leaders to be exemplars, and to foster not only compliance, but enthusiasm among members of the organization for doing things right (Carroll 1979).

The challenges of this approach are that it is expensive, time-consuming, and open-ended (Willbern 1954). While ethics training takes days or weeks, professional training generally takes months and years (Van Wart 1998). The added time takes considerable expense, especially since those conducting professional training are themselves generally more educated in order to handle the sophisticated and complex materials covered. Further, the professional integrity model as it is sometimes called, tends to encourage discussions of multiple interpretations and differing viewpoints rather than enforce a single organizational stance on issues. Some also argue that professionals as groups are as susceptible to bias as individuals, and can distort values invidiously (Adams 1993; Sanders 1993; Shadnam and Lawrence 2011).

On the whole, compliance-based approaches are reported by some to be on the rise over professionally-grounded models (Roberts 2009), but more robust forms of corporate social responsibility models that go beyond the minimums of economic viability and legal compliance are also in ascendance among elite organizations. Many companies now vie to be considered "green," good corporate citizens, preferred places to work, etc. (Meyer 2000; Porter and Kramer 2002), and even consider it a competitive advantage (Adler and Kwon 2002; Barney and Hansen 1994; Baucus and Baucus 1997), especially when they make ethics and environmental top-100 rankings. Ideally, organizations would include both approaches (Hejka-Ekins 2001), but many analysts think that this is more often the exception rather than the rule (Shahinpoor and Matt 2007) or simply a sham (Kurlantzick 2003).

\subsection{Social Responsibility Leadership: Servant, Spiritual, and CSR}

There are a number of leadership models that emphasize the importance of starting with a good end state, e.g., a decent society, and working "backwards" to determine how to use and apply rules wisely and when to use specific virtues when values compete. Social responsibility models may variously emphasize concern for others, righteousness, concern for the community, and concern for the environment. Three major variants will be discussed here: servant leadership, spiritual leadership, and corporate social responsibility leadership. Of course, numerous other "enlightened" management experts have had ethical thrusts (e.g., stewardship, Block 1993; leadership as a gift, DePree 1989; sustainability, Ferdig 2007).

Greenleaf's servant leadership philosophy (1977) is actually an ancient one that is clearly recognizable in the writings of great humanitarians such as Lao-Tzu and Jesus. The basic idea suggests that the notion of the people serving the king, prince or potentate is backwards and fundamentally wrong; rather, it is the leader who is privileged to serve the people. Furthermore, it is the improvement in well-being of the people, their empowerment, and the concomitant humility of the leader that is the measure of leadership greatness. Greenleaf continues to be highly referenced and the center of significant research (e.g., Graham 1991; Russell and Stone 2002; Sendjaya, Sarros, and Santora 2008). Greenleaf Centers have an extensive following and are not only found in the U.S and UK, but also in Europe and Asia, promoting the servant leadership philosophy, particularly popular in the nonprofit community.

A more recent variant of social responsibility leadership is spiritual leadership, used in an organizational sense and not related to the leadership of churches or religious organizations (e.g., Sanders 1967), the original meaning of the term. The movement has a very strong normative thrust, and many of the major spiritual leadership scholars have taken a more empirical approach than servant leadership, which has tended to eschew the atomization of its propositions for 
concrete testing (see Liden et al. 2008 for a recent exception). Key proponents of spiritual leadership are Louis Fry and his colleagues (e.g., Fry 2003; Fry, Vitucci and Cedillo 2005). Similar to servant leadership, the overall thrust is that the authority of action comes from those being assisted, especially those affected outside the organization. However, it tends to take a broader view of the stakeholder universe, not limited to direct clients and customers, or even to humans. A controversial aspect of spiritual leadership is workplace spirituality, in which there is commonly a distinction made between encouraging transcendence of selfishness and metaphysical purpose versus religiosity per se. It calls for organizational cultures that acknowledge there is an innate human need for spirituality and encourage a connection to universe/god/spirit (Giacalone and Jurkiewicz 2003) in the workplace. Examples of where inherent spiritual values might be particularly clear are: wellness and assistance programs, leadership that encourages servant and steward perspectives, diversity practices, bereavement programs, and socially informed management decisions.

A third perspective, squarely taking on the common perceived rift caused by capitalist competition and "selfishness" versus promoting the common good, is corporate social responsibility (CSR). CSR is based on a hierarchy of values system, roughly equivalent to Maslow's needs hierarch, but moving toward societal fulfillment at the higher stages. (Note 2) The most prominent moral philosopher undergirding corporate social responsibility is Kohlberg (1963, 1981). He established three levels of moral development that have been used by many leadership ethicists. Level 1 is pre-conventional and includes the obedience and punishment orientation (how can I avoid punishment?), and self-interest orientation (what's in it for me?) of those with immature or undeveloped moral compass. The second level is the conventional, which includes the conformity stage (instinctively following social norms) and the authority and social-order maintaining orientation (a law and order morality). The highest level is the post-conventional, which includes the social contract orientation (demonstrated in democratic state constitutions and capitalistic legal instruments), and the ultimate universal ethical principles stage (following one's own principled conscience). These levels are relatively easily transferred to the leadership process. This type of layered intellectual framework undergirds the leader exemplar literature in the public sector (e.g, Cooper 1990; Cooper and Wright 1992; Callahan 2006; Pfiffner 2003; Rugeley and Van Wart 2006).

In corporate social responsibility, the same logic of ethics applies to private companies and publicly-held corporations as it does to individuals (Kempster, Jackson, Conroy 2011). Although there are many models of corporate social responsibility that are relatively complementary (Redman 2005), the one by A. B. Carroll (1979) will be used here. He suggested a progressive model, with varying levels of responsibility. At the base or economic level, the business must provide quality goods and services that are valued by consumers. These goods and/or services in turn provide jobs to employees, a source of revenue for suppliers, profits to shareholders, and wealth to owners and senior managers. The other fundamental base value is abiding by its legal responsibilities, because if a company is not law-abiding, it risks social opprobrium at a minimum, and scandal that can bring it down in part or whole at its worst. After these absolute foundational responsibilities come ethical responsibilities, which are those that may not be required by law, but are socially accepted norms of honesty, decency, and fair-play. Companies may not be required to give ample notice when a layoff is to occur but to the degree they can forewarn employees, they are more ethical and trustworthy. Finally, there are discretionary responsibilities, which are those that include voluntary efforts to be environmentally friendly, enhance human rights, be an employer of choice, provide philanthropy, and so on. In sum, corporate social responsibility is meeting basic economic needs through diligence and innovation, exceeding legal requirement by fulfilling the spirit of the law, while simultaneously finding ways to enhance the community and planet with mutually beneficial actions, and when possible, provide outright acts of charity.

Four major propositions can be distilled from the researchers working in social responsibility leadership. First, it is firmly established on the integrity model above, but a core value not necessarily included in other perspectives is the need for leader humility. This can be argued to be potentially conflicting with the authentic leadership model emphasizing self-confidence, or largely ignored by the moral manager approach. All variations also advocate altruism and "calling" as explicit values in some form. In the public sector literature, there is a growing body of work on the importance of public service motivation (Alonso and Lewis 2001; Moynihan and Pandey 2007; Perry 1996, 1997). In other ethical leadership perspectives, these concepts tend to be wrapped in less evocative terms like commitment and dedication. Second, social responsibility leadership always puts the needs of subordinates and external constituents first. A supervisor might break up their own work pattern to assist a subordinate who was having trouble, or an intake worker may take more time with a particularly desperate client even though pressed for time herself. This also means the developmental role of the leader is primary as it is in superleadership (Manz and Sims 1989, 1991). It also implies a strong empowerment thrust. Third, servant and spiritual leaders engage in emotional labor and emotional healing. Emotional labor is the act of showing sensitivity, empathy, and compassion for others. Emotional labor is most 
extensive when negative events occur such as disasters, death, or great suffering. Although emotional labor occurs with subordinates and other organizational members, the perspective recognizes that some occupations have far greater expectations of leaders exhibiting emotional labor with clients such as social workers, emergency workers, and teachers (Gardner, Fischer, and Hunt 2009; Newman, Guy and Mastracci 2009). Finally, social responsibility leadership emphasizes end results strongly in terms of the community and environment, particularly in more contemporary versions of CSR. From this perspective, the Kohlbergian notion of integrating increasingly broad consciousness in terms of both space and time is imperative for the socially responsible leader who is deeply aware of, and concerned for, the needs of humanity and the environment.

One of the strengths of social responsibility leadership is that it taps directly into the need to assist and make a difference. Martin Luther King said that an individual has not started living until he can rise above the narrow confines of his individualistic concerns to the broader concerns of all humanity. While social scientists often eschew feelings that have quasi-religious overtones, such sentiments are so powerful that they sometimes lead people to risk their lives or change their vocations. Spiritual (or servant) leadership sets up a model that analyzes leaders of compassion and calling, and implicitly encourages all leaders to move closer to a pan-spiritual model. For example, after a long period of corporate greed and scandal, it is easy to see that many business organizations are trying to adopt a more humanitarian and "green" perspective represented in the rise of interest in consciously ethical constructs such as the triple bottom line - people, planet, and profit (Elkington 1994). However, not only is social responsibility leadership in its various forms a universalistic model, it has great opportunity to be a situational model as well. Some professions more than others are fundamentally more open to a social responsibility leadership model, especially in the nonprofit and public sectors. Ironically, another example would be the contemporary military (Farmer 2010). While conventional warfare encourages leadership that is heroic, regimented, and rugged, the nation-building activities that have been increasingly thrust on the military mean that soldiers and their supervisors must attempt to show compassion for the population, assist in community projects, and demonstrate concern for long-term sustainability.

A challenge of servant and spiritual leadership is its abstraction from normal organizational authorization procedures and functions. In more recent iterations, it includes the skill of possessing the knowledge of the organization and tasks at hand so as to be in a position to effectively support others. Another challenge is deciding whether it is a normative or empirical approach, and if the ideal methods are prescriptive or descriptive. There is some confusion about whether a more spiritual approach does or needs to make a difference to bottom line efficiency and results, or whether it is a desirable end result in and of itself. Finally, sometimes there is very strong resistance to the normative thrust of servant leadership in the private sector where the market can be seen as the primary source of wisdom, and the concerns of shareholders and owners as being paramount to the success of capitalism (a la Milton Friedman 1970).

Additional criticism relates to the motivation and implementation challenges of social responsibility leadership (Windsor 2001; Blowfield and Frynas 2005), especially when it is labeled spiritual leadership (Tourish and Tourish 2012). Since there are many 'others' such as followers, clients, and external stakeholders in social responsibility perspectives, it is routinely very difficult to decide which ones count and to what degree in the myriad decisions that organizations make with ethical elements. Because greater inclusion increases decision making complexity, length of time, and expense, it is important for organizations to be able to find ways to effectively expand the pool of those involved in some decisions and narrow it for less significant issues in order to remain appropriately efficient and effective; this is not an easy balance to strike. Organizations are sometimes concerned that servant and spiritual leadership may lead to excessive substitution and compassion for necessary market-based or legal discipline, and as problematically, to the endorsement of idiosyncratic and inconsistent social goals not well aligned with the organization's mission. When you bring spiritual values into the workplace, both public and private, there is the real challenge of dealing with the secular and religious in nonoffensive ways - a task sometimes difficult in a fractious world. For the long-term health of the organization, it is vital to ensure that "enlightened" philosophical perspectives such as corporate social responsibility are not subverted into bogus PR campaigns. As is clear in CSR, there are many varieties of good; organizations must be prepared to determine what good should prevail in what circumstances, and do so in a way that does not dilute core business competencies. Finally, an important ethical issue has been raised at the multinational level: is the CSR model of social responsibility biased toward wealthy countries?

\subsection{Transforming Leadership}

From the beginnings of the transformational and charismatic leadership renaissance in the late 1970s, major intellectual efforts were made to distinguish change-oriented and bigger-than-life leaders driven primarily by personal ego or "personalized" concerns versus those driven by "socialized" concerns. Distinctions between a transformational Mahatma Gandhi and a pseudo-transformational leader like Adolf Hitler are important (Bass and Steidlmeier 1999). 
For example, although Burns $(1978,2003)$ noted that transformational leaders as a class were concerned about change no matter whether for good or ill, or out of personal ambition or desire to do good, he also noted that the great ones were "transforming" leaders. Transforming leaders were those who understood the need for change emanating from the people, who clarified those needs, and who were able to create wholesome long-term change that would benefit society. Such leaders could transcend (or at least balance) their personal needs for fame and success with the good of the community. Ultimately, transforming leaders raise the morality of the people in Burns' perspective. His political perspective noted that transformational change can also be manipulative, for personal aggrandizement, and reactionary, based on demagoguery. Conger (1989) and others noted in the charismatic literature the importance of using personal power for good or socialized ends, rather than a personalized power orientation (Kanungo 2001; Parry and Proctor-Thompson 2002). The tools and characteristics of transforming leaders included gathering information from a wide variety of sources including clients and customers, stimulating wholesome discussion about the ideals of the organization relative to its need to survive and grow, molding a shared vision that was not solely based on beliefs of a single executive, and ensuring that the change would tend to focus on long-term benefits rather than short-term gains (Martin, Johnson and Cullen 2009; Kanter 2011). These themes have been particularly well discussed and supported in leadership literature with a public sector focus such as Heifetz's adaptive leadership model (1994) focusing on consensus building in tackling complex contemporary problems, Bryson and Crosby (1992) focusing on strategic planning on community, Carnevale (1995) focusing on the primacy of trust, and Terry (1995) focusing on public administrators as stewards or "conservators" of the public good.

A strength of this perspective is that there is no doubt that change is a major, and frequently critical, function of leaders, especially executives (Roberts 1985). Transforming leadership theory integrates managerial and normative values into a single model. Change is a heady process that can be negatively affected by ambition, posturing, image management, excessive urges to compete and dominate, egotistic desires to implement one's own vision, thirst for short-term gains, and the like. Transforming leadership is a model that requires leaders to subordinate their own needs and desires to those of the organization and affected community. Additionally, the whole idea of transforming leadership is particularly suitable to the public and nonprofit sectors, given their common good and social focus rather than the profit-oriented and individual focus more prevalent in the private sector.

A variety of potential weaknesses can also be posited (Whetsone 2002; Lipman-Blumen 2005). First, whenever theories marry descriptive and normative perspectives, the blend is always a bit complex and arbitrary. Good versus bad change and moral motives versus immoral ones are only easy to detect in the extremes. Further, correctness in leadership when measured in historical terms is as often tempered by success as by morality. Spanish "liberation" of Mexicans by Cortez from the "dictatorship" of Montezuma and "native" religions would be a different story if Cortez had been killed at his Veracruz landing site, and the Emperor had been half as crafty as the conqueror. Second, transforming leadership is still heroic to the degree that it casts change as the primary function of leaders and suggests that other leadership functions are essentially inconsequential management details. Critics can argue that this is like saying Woodrow Wilson's role in creating the defunct League of Nations was transforming, even though he failed to get his own country, the United States, to join. That is to say, his idea was grand and uplifting but ultimately the management of the process was a failure. Generals and CEOs are also all-too-aware that battle plans or product launches require excellent execution for success, which is to say management. A related point is that many who might be considered leaders do not have a mandate or need for transforming change. Nonexecutives and executives in stable environments have little direct demand for transforming leadership theory. In terms of research, the literature in this area is far too universalistic and monolithic. Transformational/transforming leadership tends to be projected as the answer to all situations or labeled unsuitable. Further, researchers invariably treat all types of transformation that leaders need to make as a single type. The area would profit greatly from a nonpresciptive analysis of the types of transformations necessary, and the types of variations that were most suitable given antecedent conditions. For example, participative decision making was in vogue when Vroom and Yetton (1973) elucidated a theory powerful in explaining inclusiveness success, and which was useful in helping practitioners retrain their decision patterns through training.

\section{The Complementarity of Different Ethical Perspectives}

A comprehensive perspective on ethical leadership is unified in the sense that leaders are supposed to take great stock of their organizational, professional, and societal communities, and integrate the common good in the leadership process. Both the means of success as well as the ends are placed in a social context that emphasizes equity and sustainability. Undergirding all ethical approaches is the personal integrity of those involved in the leadership process. The honesty, trustworthiness, and fairness of individuals is generally considered the foundation of an ethical leadership. However, the variation in the emphasis of different ethical theories is nontrivial. Virtuous leaders are scrupulous in not 
allowing integrity to be the victim of the innumerable circumstances begging them to shade and obfuscate the truth, as is frequently seen in harsh political debates or when company profits are on the line. Authentic leaders are those who take virtue to a deeper level by knowing themselves so well that their ability to be self-regulating, resilient, optimistic, nondefensive, and "other-oriented" is enhanced as they manage leadership processes. Stemming from their centeredness, authentic leaders tend to exude both wisdom and an innately positive spirit. In addition to integrity and positive traits, ethical leaders follow the appropriate dictates of society and organizations. Moral management concentrates on ensuring that legal rules and organizational strictures are carried out. Lax organizational cultures, especially in the fish-bowl public sector, can lead to scandals, public resentment, legislative investigations, demoralization of employees and other bureaupathologies. Because laws and organizational rules can be subtle, complex, and even contradictory, professional education and training are frequently necessary to sort through conflicting business values, legal precedents, and authorized procedures. Ethical leaders do not forget the ends of their corporate or public stewardship. Socially responsible leaders are extremely other-oriented. They are motivated by heartfelt empathy, concern, and compassion for those who entrust the leadership role to them. Helping others is not a problem to be dealt with for the socially responsible leader; it is the very purpose of leadership. While Mother Teresa was an extreme example of a spiritual leader, it is easy to find more prosaic examples in leaders and managers in nonprofits and a wide variety of social work agencies. Transforming leadership focuses on the important business of change, integrating a socialized perspective into the organizational and social evolution. Unlike socially responsible leadership as a scholarly focus, transforming leadership research tends to focus on processes rather than individual people. Transforming leaders are facilitators of wholesome change, and they use their skills to ensure that the need for change does not lead to either authoritarian solutions or chaotic abandonment of wicked social or organizational problems. To be sure, the ideal ethical leader incorporates all these styles all the time. In reality, leaders have ethical preferences and the needs of the ethical landscape will vary significantly, making distinctions in the various perspectives useful for analytic and practical purposes.

\section{Limitations of This Study and the Ethical Leadership Literature}

Because of its broad sweep, this study was largely limited to prominent examples in the literature. It was necessary to make generalizations about the six types of ethical leadership, even when some of the primary variants were described. To some degree distinctions among the six types of ethical leadership had to be emphasized to provide the conceptual overview that was the purpose of this article.

The individual critiques of the six ethical perspectives have already been provided and will not be repeated here. Rather, taken as a whole, three additional areas of future research seem important. First, as an integrative exercise such as was done here, the ethical leadership literature doesn't "match up" against traditional leadership literature particularly well. Why is it that the six perspectives seem to miss so much of the organizational experience? For example, at a philosophical level perhaps it is because so many important grand theories, other than intensely secular moral ones, are neglected. Some of those important theories include divine command theory, normative political economic theories (especially the capitalist/liberal economics and Marxian/critical theory versions), philosophical egoism so important to the Western experience, existentialism, natural law theory (modern day sustainability theory), and moral particularism (e.g., nihilism). (Note 3) Second, much more work has been done on the applied level regarding ethical leadership and its relationship to the theory of the firm, but it has yet to be well integrated. Third, it is surprising how unrelated the unethical leadership is to the ethical leadership literature. Currently, there is almost no coherent theoretical work connecting the two. Obversely, these weaknesses are all research opportunities.

\section{References}

Adams, G.B. (1993). Ethics and the Chimera of Professionalism: The Historical Context of an Oxymoronic Relationship. American Review of Public Administration, 23(2), 117-139.

Adams, G.B., \& Balfour, L. (1998). Unmasking Administrative Evil. Thousand Oaks, CA.: Sage.

Adler, P.S., \& Kwon, S.W. (2002, January). Social Capital: Prospects for a New Concept. Academy of Management Review, 27, 17-40.

Alonso, P., \& Lewis, G. (2001). Public service motivation and job performance: Evidence from the federal sector. American Review of Public Administration, 31(4), 363-380.

Argyris, C. (1957). Personality and Organization. New York: Harper. - (1993). Knowledge for Action. San Francisco: Jossey-Bass.

Aristotle. (1953). The Ethics of Aristotle. Trans. Thomson JAK New York: Viking Penguin. 
Avolio, B.J., \& Gardner, W.L. (2005). Authentic leadership development: Getting to the root of positive forms of leadership. The Leadership Quarterly, 16, 315-338.

Avolio, .BJ., \& Luthans, F. (2006). The High Impact Leader: Moments Matter in Accelerating Authentic Leadership Development. New York: McGraw Hill.

Barney, J.B., \& Hansen, M. (1994). Trustworthiness as a source of competitive advantage. Strategic Management Journal, Special Winter Issue, 175-190.

Bass, B.M., \& Avolio, B.J. (1990). The implications of transactional and transformational leadership for individual, team, and organizational development. In W. Pasmore and R.W. Woodman (Eds.), Research in Organizational Change and Development (vol. 1, pp. 231-272). Greenwich, CT: JAI Press.

Bass, B.M., \& Steidlmeier, P. (1999). Ethics, character, and authentic transformational leadership. The Leadership Quarterly, 10, 181-217.

Baucus, M.S., \& Baucus, D.A. (1997, February). Paying the piper: An empirical examination of longer-term financial consequences of illegal corporate behavior. Academy of Management Journal, 40, 129-151.

Bazerman, M.H., \& Tenbrunsel, A.E. (2011). Ethical breakdowns. Harvard Business Review, 809(4), 58-65.

Beck-Dudley C.L. (1996). Ethics and excellence. American Business Law Journal, 34(fall), 117-131.

Beenan, G., \& Pinto, J. (2009). Resisting organizational-level corruption: An interview with Sherron Watkins. Academy of Management Learning and Education, 8(2), 275-289.

Blake, R.R., \& Mouton, J.S. (1964). The Managerial Grid. Houston, TX: Gulf.

Block, P. (1993). Stewardship: Choosing Service over Self-Interest. San Francisco: Berrett-Koehler.

Boyatzis, R.E., \& McKee, A. (2005). Resonant Leadership. Boston: Harvard Business School Press.

Brown, M.E., \& Mitchell, M.S. (2010). Ethical and unethical leadership: Exploring new avenues for future research. Business Ethics Quarterly, 20(4), 583-616.

Brown, M.E., \& Treviño, L.K. (2006). Ethical leadership: A review and future directions. The Leadership Quarterly, $17,595-616$.

Bryson, J.M., \& Crosby, B.C. (1992). Leadership for the Common Good: Tackling Problems in a Shared-Power World. San Francisco: Jossey-Bass.

Burke, C.S., Sims, D.E., Lazzara, E.H., \& Salas, E. (2007). Trust in leadership: A multi-level review and integration. The Leadership Quarterly, 18, 606-632.

Burns, J.M. (1978). Leadership. New York: Harper and Row.

- (2003). Transforming leadership. New York: Grove Press.

Callahan, K (2006). Elmer Boyd Staats and the pursuit of good government. Public Administration Review, 66(2), 159-167.

Carnegie, D. (1936). How to Make Friends and Influence People. New York: Simon \& Schuster.

Carnevale, D.G. (1995). Trustworthy Government: Leadership and Management Strategies for Building Trust and High Performance. San Francisco: Jossey-Bass.

Caro, R.A. (1974). The Power Broker: Robert Moses and the Fall of New York. New York: Vintage Books.

Carroll, A.B. (1979, October). A three dimensional conceptual model of corporate performance. Academy of Management Review, 497-505.

Chandrasekhar, I., Wardrop ,M., \& Trotman, A. (2012). Phone hacking: Timeline of the scandal. The Telegraph, May 3.

Ciulla, J.B. (1995). Leadership ethics: Mapping the territory. Business Ethics Quarterly, 5(1), 5-28.

Ciulla, J.B. (ed.) (2004). Ethics, the Heart of Leadership (2 ${ }^{\text {nd }}$ ed.). Westport, CT: Praeger.

Ciulla, J.B. (2011). Leadership ethics in Africa. Leadership, 8(1), 3-6.

Ciulla, J.B., Price, T., \& Murphy, S. (2005). The Quest for Moral Leaders: Essays on Leadership Ethics. Northampton, MA: Edward Elgar.

Collinson, D. (2012). Prozac leadership and the limits of positive thinking. Leadership, 8(2), 87-107. 
Conger, J.A. (1989). The Charismatic Leader: Behind the Mystique of Exceptional Leadership. San Francisco: Jossey-Bass.

Cooper, D., Scandura, T.A., \& Schriesheim, C.A. (2005). Looking forward but learning from our past: Potential challenges to developing authentic leadership theory and authentic leaders. Leadership Quarterly, 16, 475-493.

Cooper, T.L. (1990). The Responsible Administrator. San Francisco: Jossey-Bass.

Cooper, T.L., \& Wright, D.N., (eds.) (1992). Exemplary Public Administrators: Character and Leadership in Government. San Francisco: Jossey-Bass.

Covey, S.R. (1990). Principle-Centered Leadership. New York: Fireside.

Dahl, R.A. (1947). The science of public administration: Three problems. Public Administration Review, 7(1), 1-11.

Dalla Costa, J. (1998). The Ethical Imperative: Why Moral Leadership Is Good Business. Reading, MA: Addison-Wesley.

DePree, M. (1989). Leadership Is an Art. New York: Doubleday.

De Toro, P. (1995). Building an ethical organization. Business Ethics: A European Review, 4(1), 43-51.

Dion, M. (2012). Are ethical theories relevant for ethical leadership? Leadership \& Organization Development Journal, 33(1), 4-24.

Dirks, K.T., \& Ferrin, D.L. (2002). Trust in leadership: Meta-analytic findings and implications for research and practice. Journal of Applied Psychology, 87(4), 611-628.

Dlouhy, J.A. (2010). Offshore drilling agency to be split in two. Houston Chronicle, May 11. Retrieved from http://www.chron.com/disp/story.mpl/business/7001009.html

Einarsen, S., Aasland, M.S., \& Skogstad, A. (2007). Destructive leadership behavior: A definition and conceptual model. The Leadership Quarterly, 18(3), 207-216.

Eisenbess, S.A. (2012). Rethinking ethical leadership: An interdisciplinary integrative approach. The Leadership Quarterly. Available online starting March 2012.

Elkington, J. (1994). Towards the sustainable corporation: Win-win-win business strategies for sustainable development. California Management Review, 36(2), 90-100.

Englund, S. (2004). Napoleon: A Political Life. Cambridge, MA: Harvard University Press.

Enriques, L., \& Volpin, P. (2007). Corporate governance reforms in continental Europe. The Journal of Economic Perspectives, 21(1), 117-140.

Erwin, R.E. (1995). The virtues appropriate to business. Business Ethics Quarterly, 5(4), 833-842.

Fairholm, G. (1991). Values Leadership: Toward a New Philosophy of Leadership. New York: Praeger.

Farmer, S. (2010). The humble leader: Servant leadership can be a powerful asset in the military. Armed Forces Journal (December). Retrieved from http://www.armedforcesjournal.com/2010/12/4906840/

Ferdig, M.A. (2007). Sustainability leadership: Co-creating a sustainable future. Journal of Change Management, 7(1), 2007.

Fineman, S. (2006). On being positive: Concerns and counterpoints. Academy of Management Review, 31(2), 270-291.

Finer, H. (1941). Administrative responsibility in democratic government. Public Administration Review, 1(4), $335-350$.

Fiorelli, P., \& Tracey, A.M. (2007). Why comply? Organizational guidelines offer a safer harbor in the storm. Journal of Corporation Law, 32(3), 467-490.

Ford, J., \& Harding, N. (2011). The impossibility of the 'true self' of authentic leadership. Leadership, 7(4), 463-479.

Friedman, M. (1970). The social responsibility of business is to increase its profits. New York Times Magazine (September 13), pp. 30, 126-127.

Friedrich, C.J. (1940). The nature of administrative responsibility. In Carl Friedrich (Ed.), Public Policy. Cambridge, MA: Harvard University Press.

Fry, L.W. (2003). Toward a theory of spiritual leadership. The Leadership Quarterly, 14, 693-727.

Fry, L.W., Vitucci, S., \& Cedillo, M. (2005). Spiritual leadership and army transformation: Theory, measurement, and 
establishing a baseline. The Leadership Quarterly, 16, 835-862.

Gardner, W.L., Fischer, D., \& Hunt, J.G. (2009). Emotional labor and leadership: A threat to authenticity? The Leadership Quarterly, 20, 466-482.

George, B. (2003). Authentic Leadership: Rediscovering the Secrets to Creating Lasting Value. San Francisco: Jossey-Bass.

Giacalone, R.A., and Jurkiewicz, C.L. (2003). Handbook of Workplace Spirituality and Organizational Performance. New York: M.E. Sharpe.

Gilman, S.C. (2001). Organizations, transparency and the fight against corruption: Institutions of integrity in the United States. Organization for Economic Development (OECD). Online.

Goldman, A. (2006). High toxicity leadership: Borderline personality disorder and the dysfunctional organization. Journal of Managerial Psychology, 21(8), 733-746.

Goleman, D., McKee, A., \& Boyatzis, R.E. (2002). Primal Leadership: Realizing the Power of Emotional Intelligence. Boston: Harvard Business School Press.

Goodsell, C. (2003). The Case for Bureaucracy ( $4^{\text {th }}$ ed.). Chatham, NJ: Chatham House.

Graen, G., \& Uhl-Bien, M. (1995). Relationship-based approach to leadership: Development of leader-member exchange (LMX) theory of leadership over 25 years: Applying a multi-level multi-domain approach. The Leadership Quarterly, 6(2), 219-247.

Graham, J.W. (1991). Servant leadership in organizations: Inspirational and moral. The Leadership Quarterly, 2, 105-119.

Greenleaf, R.K. (1977). Servant Leadership: A Journey into the Nature of Legitimate Power and Greatness. New York: Paulist Press.

Hackman, J.R. (2009). The perils of positivity. Journal of Organizational Behavior, 30(2), 309-319.

Heifetz, R.A. (1994). Leadership Without Easy Answers. Cambridge, MA: Belknap Press.

Hejka-Ekins, A. (2001). Ethics in in-service training. In Terry Cooper (Ed.), Handbook of Administrative Ethics (2 ${ }^{\text {nd }}$ ed., pp. 79-103). New York: Marcel Dekker.

Hersey, P., \& Blanchard, K.H. (1969). Life cycle theory of leadership. Training and Development Journal, 23(1), $26-34$.

Hill, R.P., Stephens, D.L., \& Pamplin, R.B. (2005). The multiplicity of selves and selves management: A leadership challenge for the $21^{\text {st }}$ century. Leadership, 1(1), 127-140.

Hilliard, V.B. (2001). Beyond the confines of compliance and virtue: Honing a set of global ethics for South Africa and the United States of America. Public Administration Quarterly, 25(3), 436-461.

Hood, C. (1996). Beyond progressivism: A new 'global paradigm' in public management? International Journal of Public Administration, 19(2), 151-177.

Howard, P. (1994). The Death of Common Sense: How Law is Suffocating America. New York: Random House.

Ip, P.K. (2011). Practical wisdom of Confucian ethical leadership: A critical inquiry. Journal of Management Development, 30(7/8), 685-696.

Johnson, C.R. (2005). Meeting the Ethical Challenge of Leadership ( $2^{\text {nd }}$ ed.). Thousand Oaks, CA: Sage.

Judge, T.A., Piccolo, R.F., \& Kosalka, T. (2009). The bright and dark Sides of leader traits: A review and theoretical extension. The Leadership Quarterly, 20, 855-875.

Kaiser, R.B., Hogan, R., \& Craig, S.B. (2008). Leadership and the fate of organizations. American Psychologist, 63(2), 96-110.

Kammeyer-Mueller, J.D., Simon, L.S., \& Rich, B.L. (2012). The psychic cost of doing wrong: Ethical conflict, divestiture socialization, and emotional exhaustion. Journal of Management, 38(3), 784-808.

Kant, I. (1787/1996). Critique of Pure Reason. Indianapolis, IN: Hackett Publishing.

Kanter, R.M. (2011). How great companies think differently. Harvard Business Review, 89(11), 66-78.

Kanungo, R.N. (2001). Ethical values of transactional and transformational leaders. Canadian Journal of Administrative Sciences, 18(4), 257-265. 
Kapstein, M., \& Schwartz, M.S. (2008). The effectiveness of business codes: A critical examination of existing studies and the development of an integrated research model. Journal of Business Ethics, 77(2), 111-127.

Kempster, S., Jackson B., \& Conroy, M. (2011). Leadership as purpose: Exploring the role of purpose in leadership practice. Leadership, 7(3), 317-334.

Kets de Vries, M.F.R. (1985). Narcissism and leadership: An object relations perspective. Human Relations, 38, 583-601.

Kodish, S. (2006). The paradoxes of leadership: The contribution of Aristotle. Leadership, 2(4), 451-468.

Kohlberg, L. (1963). Moral develop and identification. In Harold Stephenson (Ed.), Child Psychology (pp. 277-332). Chicago: University of Chicago Press.

Kohlberg, L. (1981). The Philosophy of Moral Development: Moral Stages and the Idea of Justice, volume 1. New York: Simon \& Schuster.

Kouzes, J.M., \& Posner, B.Z. (1993). Credibility: How Leaders Gain and Lose It, Why People Demand It. San Francisco: Jossey-Bass.

Kurlantzick, J. (2003, October). Liar, liar: In the race to make money, some American businesses have been lying their pants off-but is success at any cost really worth the price? Entrepreneur, (4), 69-74.

Ladkin, D. (2006). When deontology and utilitarianism aren't enough: How Heidegger's notion of “dwelling" might help organizational leaders resolve ethical issues. Journal of Business Ethics, 65, 87-98.

Lichtenstein, B.M., Smith, B.A., \& Torbert, W. (1995). Leadership and ethical development: Balancing light and shadow. Business Ethics Quarterly, 5(1), 97-116.

Liden, R.C., Wayne, S.J., Zhao, H., \& Henderson, D. (2008). Servant leadership: Development of a multidimensional measure and multi-level assessment. The Leadership Quarterly, 19, 161-177.

Lipman-Blumen, J. (2005). The Allure of Toxic Leaders: Why We Follow Destructive Bosses and Corrupt Politicians - and How We Can Survive Them. New York: Oxford University Press.

Litzky, B.E., Eddleston, K.A., \& Kidder, D.L. (2006). The good, the bad, and the misguided: How managers inadvertently encourage deviant behaviors. Academy of Management Perspectives, 20(1), 91-103.

Louden, R. (1984). Some vices of virtue ethics. The American Philosophical Quarterly, 21(3), 227-236.

Luthans, F. (2003). The need for and meaning of positive organizational behavior. Journal of Organizational Behavior, $23,695-706$.

Luthans, F., \& Youssef, C.M. (2007). Emerging positive organizational behavior. Journal of Management, 33(3), 321-349.

Machiavelli, N. (1998). The Prince. Oxford, England: Oxford University Press.

MacIntyre, A. (1981). After Virtue: A Study in Moral Theory. Notre Dame, IN: University of Notre Dame Press.

Mackie, J.L. (1977). Ethics: Inventing Right and Wrong. London: Penguin Press.

Manz, C.C. (1989). Superleadership: Leading Others to Lead Themselves. Englewood Cliffs, NJ: Prentice Hall.

. (1991). Superleadership: Beyond the Myth of heroic leadership. Organizational Dynamics, 19, 18-35.

Manz, C.C., Anand, V., Joshi, M., \& Manz, K. (2008). Emerging paradoxes in executive leadership: A theoretical interpretation of the tensions between corruption and virtuous values. The Leadership Quarterly, 19, 385-392.

Martin, K.D., Johnson, J.L., \& Cullen J.B. (2009). Organizational change, normative control deinstitutionalization, and corruption. Business Ethics Quarterly, 19(1), 105-130.

May, D.R., Chan, A.Y.L., Hodges, T.D., \& Avolio, B.J. (2003). Developing the moral component of authentic leadership. Organizational Dynamics, 32(3), 247-260.

McKendall, M., DeMarr, B., \& Jones-Rikker, C. (2002). Ethical compliance programs and corporate illegality: Testing the assumptions of corporate sentencing guidelines. Journal of Business Ethics, 37(4), 367-383.

Menzel, D.C. (2007). Ethics Management for Public Administrators: Building Organizations of Integrity. Armonk, NY: M.E. Sharpe.

Meyer, H. (2000). The greening of corporate America. Journal of Business Strategy. 21(), 38-43.

Mill, J.S. (1863/1906, January/February). Utilitarianism. Chicago, IL: University of Chicago Press. 
Miller, M. (2002). Enron's ethics code reads like fiction. Business First of Columbus. March 29, Viewpoint section.

Morse, J. (1999). The missing link between virtue theory and business ethics. Journal of Applied Philosophy, 16(1), 47-58.

Moynihan, D.P., \& Pandey, S.K. (2007). The role of organizations in fostering public service motivation. Public Administration Review, 67(1), 40-53.

Newell, T., Reeher, G., \& Ronayne, P. (2008). The Trusted Leader: Building the Relationships that Make Government Work. Washington, DC: CQ Press.

Newman, M.A., Guy, M.E., \& Mastracci, S.H. (2009). Affective leadership and emotional labor. Public Administration Review, 69(1), 6-20.

Norma, S., Avolio, B., \& Luthans, F. (2010). The Impact of positivity and transparency on trust in leaders and their effectiveness. The Leadership Quarterly, 18(3), 350-364.

O’Leary, R. (2006). The Ethics of Dissent: Managing Guerrilla Government. Washington, D.C.: CQ Press.

Ostrom, V. (1996). The challenge of the quest for excellence. International Journal of Public Administration, 19(2), 125-149.

Pache, A., \& Santos, F. (2010). When worlds collide: The internal dynamics of organizational responses to conflicting institutional demands. Academy of Management Review, 35(3), 455-476.

Padilla, A., Hogan, R., \& Kaiser, R.B. (2007). The toxic triangle: Destructive leaders, susceptible followers, and conducive environments. The Leadership Quarterly, 18, 176-194.

Palanski, M.E., \& Yammarino, F.J. (2009). Integrity and leadership: A multi-level conceptual framework. The Leadership Quarterly, 20, 405-420.

Parry, K.W., \& Proctor-Thomson, S.B. (2002). Perceived integrity of transformational leaders in organizational settings. Journal of Business Ethics, 35, 76-96.

Payne, G.T., Brigham, K.H., Broberg, J.C., Moss, T.W., \& Short, J.C. (2011). Organizational virtue orientation and family firms. Business Ethics Quarterly, 21(2), 257-285.

Peale, N.V. (1952). The Power of Positive Thinking. New York: Prentice Hall.

Perry, J.L. (1996). Measuring public service motivation: An assessment of construct reliability and validity. Journal of Public Administration Research and Theory, 6(1), 5-22.

. (1997). Antecedents of public service motivation. Journal of Public Administration Research and Theory, 7(2), 181-197.

Peters, T. (1991). Excellence in government? I'm all for it! Maybe. Bureaucrat, 20(1), 3-6.

Pfiffner, J.P. (2003). Elliot L. Richardson: Exemplar of integrity and public service. Public Integrity, 5(3), 251-270.

Phillips, D.T., \& Loy, J.M. (2003). Character in Action: The U.S. Coast Guard in Action. Annapolis MD: Naval Institute Press.

Porter, M., \& Kramer, M.R. (2002, December). The competitive advantage of corporate philanthropy. Harvard Business Review, 57-68.

Powers, R.G. (1987). Secrecy and Power: The Life of J. Edgar Hoover. New York: Free Press.

Reed, G.E. (2012). Leading questions: Leadership, ethics, and administrative evil. Leadership, 8(2), 187.

Roberts, N.C. (1985). Transforming leadership: A process of collective action. Human Relations, 38, 1023-1046.

Roberts, R. (2009). The rise of compliance-based ethics management. Public Integrity, 11(3), 261-277.

Rohr, J.A. (1989). Ethics for Bureaucrats. New York: Marcel Dekker.

Rosenthal, S.A., \& Pittinsky, T.L. (2006). Narcissistic Leadership. The Leadership Quarterly, 17, 617-633.

Rost, J.C. (1990). Leadership for the Twenty-First Century. Westport, CT: Praeger.

Rugeley, C., \& Van Wart, M. (2006). Everyday moral exemplars: The case of Sam Medina. Public Integrity, 8(4), 381-394.

Russell, R.F., \& Stone, A.G. (2002). A review of servant leadership attributes: Developing a practical model. Leadership \& Organization Development, 23(3), 145-157. 
Sanders, J.O. (1967). Spiritual Leadership. Peabody, MA: Moody Press.

Sandler, J. (2007). The War on Whistleblowers. Salon.com.

Sandowsky, D. (1995). The charismatic leader as narcissist: Understanding the abuse of power. Organizational Dynamics, 24(4), 57-71.

Schilling, J. (2009). From ineffectiveness to destruction: A qualitative study on the meaning of negative leadership. Leadership, 5(1), 102-128.

Sergiovanni, T.J. (2007). Rethinking Leadership ( $2^{\text {nd }}$ ed.). Thousand Oaks, CA: Corwin Press (Sage).

Shadnam, M., \& Lawrence, T.B. (2011). Understanding widespread misconduct in organizations: An institutional theory of moral collapse. Business Ethics Quarterly, 21(3), 379-407.

Shahinpoor, N., \& Matt, B.F. (2007). The power of one: Dissent and organizational life. Journal of Business Ethics, 74(1), 37-48.

Shaw, J. (2010). Papering the cracks with discourse: The narrative identity of the authentic leader. Leadership 6(1), $89-108$.

Shipman, A., \& Mumford, M. (2011). When confidence is detrimental: Influence of overconfidence on leadership effectiveness. The Leadership Quarterly, 22(4), 649-665.

Seligman, E.P., Steen, T.A., Park, N., \& Peterson, C. (2005). Positive psychology progress: Empirical validation of interventions. American Psychologist, 60(5), 410-421.

Sendjaya, S., Sarros, J.C., \& Santora, J.C. (2008). Defining and measuring servant leadership behaviour in organizations. Journal of Management Studies, 45(2), 402-424.

Sheth, N.R. (2005). Ancient wisdom for a knowledge society: A worm's eye view. The Journal of Entrepreneurship, 14(2), 91-102.

Sinclair, A. (2010). Placing self: How might we place ourselves in leadership studies differently? Leadership, 6(4), $447-460$

Singh, J.B. (2001). Determinants of the effectiveness of corporate codes of ethics: An empirical study. Journal of Business Ethics, 101(3), 385-395.

Smith, J., \& Dubbink, W. (2011). Understanding the role of moral principles in business ethics: A Kantian perspective. Business Ethics Quarterly, 21(2), 205-231.

Solomon, R.C. (1992). Ethics and Excellence: Cooperation and Integrity in Business. New York: Oxford University Press.

Stansbury, J. (2009). Reasoned moral agreement: Applying discourse ethics within organizations. Business Ethics Quarterly, 19(1), 33-56.

Stouten, J., van Dijke, M., \& De Cremer, D. (2012). Ethical leadership: An overview and future perspectives. Journal of Personnel Psychology, 11(1), 1-6.

Sullivan-Gould, M. (2011). A reflection on corruption. Local Government Lawyer. Retrieved April 20, 211, from http://www.localgovernmentlawyer.co.uk

Svara, J. (2007). Ethics Primer for Public Administrators in Government and Nonprofit Organizations. Sudbury, MA: Jones and Bartlett.

Temple, O.E. (2012). Metaphysical challenges of ethical leadership in Africa. Leadership, 8(1), 47-65.

Terry, L.D. (1995). Leadership of Public Bureaucracies: The Administrator as Conservator. Thousand Oaks, CA: Sage.

Thoms, J.C. (2008). Ethical integrity in leadership and organizational moral culture. Leadership, 4(4), 419-442.

Tourish, D., \& Tourish, N. (2010). Spirituality at work, and its implications for leadership and followership: A post-structuralist perspective. Leadership, 6(2), 207-224.

Transparency International. Retrieved from http://www.transparency.org

Treviño, L.K. (1992). The social effects of punishment in organizations: A justice perspective. Academy of Management Review, 17(4), 647-676.

Treviño, L.K., \& Brown, M.E. (2005). The role of leaders in influencing unethical behavior in the workplace. In R. 
Kidwell \& C. Martin (Eds.) Managing Organizational Deviance. Thousand Oaks, CA: Sage, pp.69-87.

Treviño, LK, Weaver G.R., \& Reynolds S.J. (2006). Behavioral ethics in organizations: A review. Journal of Management, 32, 951-990.

Trottier, T., Van Wart, M., \& Wang, X. (2008). Examining the nature and significance of leadership in government organizations. Public Administration Review, 68(2), 319-333.

Valentine, S., \& Barnett, T. (2003). Ethics code awareness, perceived ethical values, and organizational commitment. Journal of Personnel Selling \& Sales Management, 23(4), 359-367.

Van Der Wal, Z., Huberts, L., Van den Heuvel, H., \& Koltoff, E. (2006). Central values of government and business: Differences, similarities and conflicts. Public Administration Quarterly, 30(3), 314-364.

Van Wart, M. (1998). Changing Public Sector Values. New York: Garland.

Vroom, V.H., \& Yetton, P.W. (1973). Leadership and Decision-making. Pittsburgh: University of Pittsburgh Press.

Walker, D. (2009). [Walker Review:] A review of corporate governance in UK banks and other financial industry entities. London: HM Treasury.

Warner, C.H., \& Appenzeller, G. (2011, September/November). Engaged leadership: Linking the professional ethic and battlefield behaviors. Military Review, 61-69.

Whetsone, J.T. (2002). Personalism and moral leadership: The servant leader with a transforming vision. Business Ethics: A European Review, 11(4), 385-392.

Willbern, Y. (1954). Professionalization in the public service: Too little or too much? Public Administration Review, 14(winter), 13-21.

Wilson, J.Q., \& Kelling, G. (1982). Broken windows. The Atlantic Monthly, 249(3), 29-38.

Windsor, D. (2001). The future of corporate social responsibility. The International Journal of Organizational Analysis, 9(3), 225-256.

Wright, T.A. (2003). Positive organizational behavior: An idea whose time has truly come. Journal of Organizational Behaviour, 24, 437-442.

Zhu, W., Norman, S.M., Peng, Z., Riggio, R.E., \& Sosik, J.J. (2012). The impact of ethical leadership on the public: The mediating role of confidence in political leaders. Leadership, 8, 109-124.

\section{Notes}

Note 1. Aristotle's list (which varies slightly in different texts) is one of the first and most important, emphasizing wisdom and prudence and encompassing good characteristics such as honesty, temperance, gentleness, balanced ambition, courage, generosity, and magnanimity. The great religious philosopher, Thomas Aquinas, listed the cardinal virtues as prudence, temperance, justice, and fortitude, as well as the three theological virtues: faith, hope, and charity. These are similar but not identical to the heavenly virtues with their handy countervailing vices. An example of a religious list is the Muslim emphasis on prayer, repentance, honesty, loyalty, sincerity, frugality, prudence, moderation, self-restraint, discipline, perseverance, patience, hope, dignity, courage, justice, tolerance, wisdom, good speech, respect, purity, courtesy, kindness, gratitude, generosity, and contentment. While the utilitarian philosopher Bentham gave equal weight to all virtues that enhanced happiness, his successor Mill emphasized superior virtues including truth, beauty, love, justice, freedom, and friendship because of long-term contribution to happiness. American founders had their own personal lists: Franklin's was 13 virtues while Washington's included innumerable points of etiquette and numbered 110 rules of conduct including as last: "Labor to keep alive in your breast that little spark of celestial fire called conscience." Virtues have also been applied at the organizational level, such as by Van Der Wal (2011; honesty, accountability, expertise, reliability) and Payne et al. (2011; corporate integrity, empathy, warmth, courage, conscientiousness). Note that organizational virtue lists tend to be more pragmatic (not surprisingly) in emphasizing accountability, reliability, and conscientiousness.

Note 2. Most, but not all CSR models assume a hierarchy of values or stages. A prominent variant of social responsibility that does not assume a hierarchy is The Triple Bottom Line in which people, profits, and planet are equal considerations for ethical business.

Note 3. Some of these philosophical perspectives are more present in the critique of the various schools of ethical leadership. Existential (and postmodern) as well as critical theory are evident in the critique of the literature itself. 